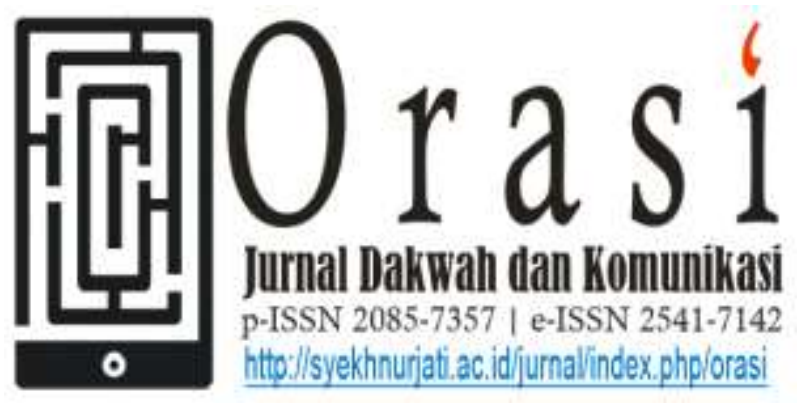

Volume 11 No. 1 Juli 2020

\title{
KONSTRUKSI BERITA UCAPAN SELAMAT NATAL DI NU ONLINE
}

\section{NEWS CONSTRUCTION OF CHRISTMAS GREETINGS ON NU ONLINE}

\author{
Siti Mariyam \\ Program Studi Komunikasi dan Penyiaran Islam, IAIN Madura \\ e-mail : sitimariyam@iainmadura.ac.id
}

\begin{abstract}
ABSTRAK
Perbedaan pendapat tentang ucapan selamat Natal setiap tahun selalu saja terjadi di kalangan ulama dan masyarakat. Hal ini membuat media massa tertarik untuk memberitakan persoalan tersebut. Pada kesempatan yang sama NU Online sebagai media Islam juga turut memberitakan persoalan ucapan selamat Natal. Penelitian ini bertujuan untuk mengetahui konstruksi berita yang dibangun oleh NU Online terkait ucapan selamat Natal. Analisis framing model Robert Entmant mencoba melihat bagaimana peristiwa atau realitas tersebut dibingkai dan dengan cara apa peristiwa atau realitas tersebut dibentuk, sehingga sampailah pada hasil penelitian yang menunjukkan bahwa NU Online membingkai berita ucapan selamat Natal sebagai bagian dari toleransi, yaitu sebuah tindakan saling menghargai dan menghormati satu sama lain tanpa harus mengganggu kepercayaan dan keyakinan masing-masing. Dengan demikian, ucapan selamat Natal dalam frame NU Online tidak lagi mengarah pada persoalan teologi, tetapi lebih pada hubungan sosial, bahwa pada prinsipnya ajaran dalam agama Islam terdapat dua hubungan individu dengan individu yang lainnya: selain hubungan seagama juga terdapat hubungan se-kemanusiaan. Oleh karena itu, apabila terdapat umat agama lain yang merayakan hari raya mereka, wajar saja jika mengucapkan selamat atas hari raya antar pemeluk agama tanpa melibatkan persoalan akidah dan keyakinan.
\end{abstract}

Kata Kunci: Konstruksi Berita, NU Online, Ucapan Selamat Natal

\section{ABSTRACT}

Difference of opinions about Christmas greetings always occurs every year among scholars and the community. This makes the mass media interested in reporting the issue. One of the media interested is NU Online, an Islamic media. This research aimed to describe the construction of news built by NU Online regarding 
Christmas greetings. Robert Entmant's framing analysis model tried to see how the event or reality was framed and in what way the event or reality was formed, which led to the results of the research showing that NU Online framed the Christmas greeting news as a part of tolerance, which is an act of mutual respect without having to interfere with each other's beliefs and faiths. Thus, the Christmas greetings in the NU Online frame no longer referred to theological issues, but rather to social relations, which the teachings of Islam also talk about. In addition to religious relationships, there are also humanitarian relationships. Therefore, if there are other religious communities who are celebrating their religious holidays, it is fine to congratulate them without involving issues of faith and belief.

Keywords: Christmas Greetings, News Construction, NU Online

\section{Pendahuluan}

Perayaan hari besar agama-agama di Indonesia mendapat apresiasi besar dari pemerintah, apresiasi tersebut diterapkan dengan menetapkan hari besar agama sebagai hari libur nasional. Ada yang menarik mengenai perayaan hari besar nasional tersebut, yakni perayaan Natal umat Kristiani pada tanggal 25 Desember. Bagi umat Kristiani Natal dipercaya sebagai hari kelahiran Yesus Kristus yang disebutkan dalam Al-Quran sebagai Nabi Isa A.S.

Umat Islam sebagai kelompok mayoritas terbesar di Indonesia berusaha untuk hidup rukun dengan umat Kristiani, mengingat kerukunan antar umat beragama merupakan salah satu fondasi utama dalam memelihara hubungan yang baik, damai, tidak bertengkar, tidak gerak, bersatu hati dan bersepakat antar umat beragama yang berbeda-beda agama untuk hidup rukun (Liliweri 2001). Hidup rukun diperlukan pengertian antar sesama yang biasa disebut toleransi.

Salah satu bentuk toleransi umat Islam biasa diterapkan dengan memberikan ucapan selamat Natal bagi umat Kristiani. Meskipun di sisi yang lain, terdapat banyak perbedaan pendapat di kalangan para ulama tentang boleh atau tidaknya (haram) umat muslim memberikan ucapan selamat Natal.

Perbedaan pendapat tersebut masih saja terjadi sampai saat ini, hingga menarik perhatian media massa untuk memberitakan mengenai polemik ucapan selamat Natal pada umat Kristiani. Pandangan ulama pun beragam, mulai dari memperbolehkan dengan alasan toleransi, kehidupan jangka panjang, serta alasan lainnya, dan pandangan yang mengharamkan pun juga terdapat dari para ulama dengan alasan menyangkut syariat agama.

Banyak media massa yang menyajikan berita ucapan selamat Natal, utamanya media yang berbasis Islam. Salah satunya adalah media massa NU Online. NU Online sebagai media Islam juga turut memberitakan ucapan selamat Natal yang belakangan ini menjadi polemik di dalam tubuh Islam sendiri. Mengingat sifat dan pekerjaan media massa adalah menceritakan peristiwa-peristiwa, maka kesibukan utama media massa adalah mengkonstruksi berbagai realitas yang akan disampaikan pada khalayak. Media menyusun realitas dari berbagai peristiwa yang terjadi, 
hingga menjadi cerita atau wacana yang bermakna. Sementara, sebuah pemberitaan tidaklah hadir tanpa dasar dan alasan, media memiliki maksud dan tujuan tersendiri, serta mempunyai wacana tertentu yang ingin disampaikan kepada khalayak. Artinya, seluruh isi media tiada lain adalah realitas yang telah dikonstruksi (constructed reality) dalam bentuk wacana yang bermakna (Maryam 2016).

Konstruksi sosial tidak berlangsung dalam ruang hampa, namun sarat dengan kepentingan-kepentingan (Bungin 2008). Bagi kaum konstruktivisme, realitas itu hadir dalam keadaan subjektif. Realitas tercipta lewat konstruksi, sudut pandang dan ideologi media. Sebuah teks dalam sebuah berita tidak dapat disamakan sebagai cerminan dari realitas, tetapi ia harus dipandang sebagai konstruksi atas realitas.

Dalam perspektif ini, tahapan-tahapan proses konstruksi sosial media massa terjadi melalui: tahap menyiapkan materi konstruksi; tahap sebaran kostruksi; tahap pembentukan konstruksi; tahap konfirmasi (Bungin 2008). Pertama, tahap menyiapkan materi konstruksi. Terdapat tiga hal penting dalam tahapan ini, yakni keberpihakan media massa pada kapitalisme, keberpihakan semu kepada masyarakat, keberpihakan kepada kepentingan umum. Kedua, tahap sebaran konstruksi. Dasar atau prinsip dari sebaran konstruksi sosial media massa adalah semua informasi harus sampai pada khalayak secara tepat berdasarkan agenda media, sesuatu yang dipandang penting oleh media, menjadi penting pula bagi khalayak. Ketiga, tahap pembentukan konstruksi realitas. Pembentukan konstruksi berlangsung melalui: (1) konstruksi realitas pembenaran; (2) kesediaan dikonstruksi oleh media massa; (3) sebagai pilihan konsumtif. Keempat, tahap konfirmasi. Tahapan ini adalah tahapan ketika media massa maupun penonton memberi argumentasi dan akuntabilitas terhadap pilihannya untuk terlibat dalam pembentukan konstruksi.

$$
\text { Kovach dan Rosentiel }
$$
menyebutkan bahwa media massa adalah sebuah sarana utama dan paling besar, bagaimana sebuah pesan dapat disampaikan secara langsung dan serentak. Media massa memiliki kemampuan tertentu dalam menciptakan citra realitas orang, benda atau peristiwa-peristiwa yang terjadi. Media secara langsung berperan aktif dalam menafsirkan realitas untuk disajikan kepada khalayak.

Penelitian ini dilakukan untuk mengetahui bagaimana konstruksi berita ucapan selamat Natal di media NU Online. Hal ini dilakukan mengingat ucapan selamat Natal masih menimbulkan pro-kontra di kalangan ulama Islam.

\section{Metodologi Penelitian}

Penelitian ini menggunakan pendekatan kualitatif dengan perspektif atau paradigma konstruksionis. Eriyanto (2011) mengatakan, pendekatan konstruksionis yang terdapat pada analisis framing akan mencakup aspek etika, moral, dan nilai-nilai tertentu dari pemberitaan yang ada. Wartawan (media) bukanlah robot yang meliput apa adanya berdasarkan apa yang dia lihat, namun berdasarkan etika dan moral yang dalam 
banyak hal berarti keberpihakan pada satu kelompok atau nilai tertentu yang umumnya dilandasi oleh keyakinan tertentu. Hal ini merupakan bagian yang integral dan tidak terpisahkan dalam membentuk dan mengkonstruksi realitas. Wartawan dalam hal ini bukan hanya sebagai pelapor, karena disadari atau tidak ia menjadi partisipan dari keragaman penafsiran dan subjektivitas publik. Oleh karena itu, wartawan menulis berita bukan hanya sebagai penjelas, tetapi juga mengkonstruksi peristiwa melalui dirinya sendiri dengan realitas yang diamatinya.

Objek dalam penelitian ini adalah narasi (teks berita) periode Desember $2018 \mathrm{di}$ media NU Online yang secara khusus membahas problematika ucapan selamat Natal (alamat URL www.nu.or.id). Adapun periode waktu publikasi dipilih sebagai objek penelitian, didasarkan pada pertimbangan bahwa pemberitaan tersebut mencapai puncaknya pada bulan Desember menjelang dan setelah perayaan Natal, hal tersebut ditandai dengan banyaknya berita terkait ucapan selamat Natal yang dipublikasikan di bulan Desember. Pemilihan rentang waktu tersebut diharapkan mampu menjadi sampel penelitian untuk melihat bagaimana ucapan selamat Natal diproduksi di media NU Online.

Setelah terkumpul data-data yang berupa teks dari berita ucapan selamat Natal di Media NU Online, peneliti kemudian menganalisis data dengan menggunakan analisis framing. Analisis framing adalah salah satu metode analisis teks yang berada dalam kategori penelitian konstruksionis. Paradigma ini memandang realitas kehidupan sosial bukanlah realitas yang natural, tetapi hasil dari konstruksi. Setiap media massa dapat berbedabeda dalam mengkonstruksi isu yang terjadi. Jadi, konsentrasi analisis paradigma konstruksionis adalah menemukan bagaimana peristiwa atau realitas tersebut dikonstruksi dan dengan cara apa konstruksi tersebut dibentuk (Eriyanto 2011).

Analisis yang digunakan dalam penelitian ini adalah analisis framing model Robert Entmant. Entmant menjelaskan bahwa ada empat elemen utama yang diikhtisarkan dalam tabel di bawah ini (Eriyanto 2011):

Tebel 1.

Elemen Framing Robert N. Entman

\begin{tabular}{ll}
\hline \multicolumn{1}{c}{ Elemen Framing } & \multicolumn{1}{c}{ Yang Ingin Dilihat } \\
\hline Define Problems & $\begin{array}{l}\text { Masalah dibingkai } \\
\text { sebagai apa }\end{array}$ \\
\hline Diagnose Causes & Logika sebab akibat \\
& terkait masalah tersebut \\
\hline Make Moral & Nilai moral yang \\
Judgement & ditonjolkan media \\
\hline Treatment & Solusi yang di \\
Recommendation & tonjolkan dalam \\
& bingkai berita \\
\hline
\end{tabular}

Framing Media model Robert N. Entman menekankan pada dua dimensi besar: seleksi isu dan penekanan atau penonjolan aspek-aspek tertentu dari realitas (Eriyanto 2011). Artinya, Robert Entmant secara spesifik mengarahkan framing pada tujuan menganalisa proses seleksi dari berbagai aspek realitas, sehingga bagian tertentu dari peristiwa itu lebih menonjol dibandingkan aspek lain. Ia juga menyertakan penempatan informasi-informasi dalam konteks yang khas, sehingga sisi tertentu 
mendapatkan alokasi lebih besar dari pada sisi yang lain.

\section{Hasil dan Pembahasan}

\subsection{Konstruksi Berita Ucapan Selamat Natal di NU Online: Bagian dari Toleransi}

Media NU Online memuat sebanyak empat berita yang secara khusus membahas ucapan selamat Natal pada edisi Desember 2018, antara lain "Ragam Pendapat Ulama soal Mengucapkan Selamat Natal", sebuah artikel sebagai pembuka berita menjelang perayaan Natal tanggal 25 Desember 2018. Disusul dengan berita "Kata Prof Quraish Shihab soal Muslim Ucapkan 'Selamat Natal"' yang menyajikan pendapat pribadi Prof. Quraish Shihab. Sebagai penguat berita di awal, media NU Online juga menyajikan hasil wawancara dengan Ketua Komisi Dakwah dan Pengembangan Masyarakat MUI yang notabene memiliki otoritas dalam membahas persoalan-persoalan Agama "Imbauan MUI kepada Umat Islam di Hari Natal". Kemudian disusul kembali dengan berita "Ucapan Selamat atas Hari Besar Agama Lain adalah Bentuk Penghormatan", yakni pendapat Ketua Umum Yayasan Indonesia Conference on Religion and Peace (ICRP).

\subsection{Define Problems}

Menurut Entman, elemen pertama kali yang dapat kita lihat mengenai framing adalah define problems. Elemen ini merupakan master frame (bingkai utama) dalam sebuah frame media. Titik tekannya adalah pada bagaimana peristiwa atau isu tertentu dipahami oleh wartawan. Peristiwa yang sama dapat dipahami secara berbeda dan disajikan dengan bingkai yang berbeda pula. Bingkai yang berbeda jelas melahirkan realitas bentukan yang berbeda pula. (Entman dalam Eriyanto 2011),

Dalam menyajikan berita ucapan selamat Natal, pertama-tama media NU Online memilih mendefinisikan masalah (define problems) ucapan selamat Natal sebagai persoalan toleransi. Artinya,. Berita yang termuat di media Online secara keseluruhan disorot dari aspek toleransi, bukan dari aspek akidah ataupun aspek-aspek yang lainnya. Penuturan masalah dalam pemberitaan ditarik ke wilayah toleransi. Singkatnya, bingkai toleransi menjadi bingkai yang dominan dalam pemberitaan ucapan selamat Natal di media NU Online. Hal tersebut dapat terlihat dalam beberapa teks berita berikut:

"Menurutnya, mengucapkan seperti itu hanya untuk toleransi."

"...baik umat Islam atau pun umat Kristen sama-sama menghormati Nabi Isa as. Sebagaimana Nabi Muhammad saw., Nabi Isa as. juga menerima ajaran agama dari Allah."

Namun demikian, maksud toleransi yang terkonstruksi dalam berita ucapan selamat Natal di Media NU Online bukan dalam pengertian mencampur adukkan keyakinan agama lain, apalagi persamaan agama, melainkan toleransi dalam batasan saling menghargai dan menghormati, sehingga bisa hidup rukun dan damai dengan tetap menjaga dan berpegang teguh pada (Akidah Islamiah).

"Mengucapkan selamat atas hari besar agama lain dianggap sebagai salah satu bentuk dari ikatan ukhuwah 
basyariah antara sesama umat manusia. Ungkapan selamat seperti itu juga merupakan sebuah penghargaan atas kebahagiaan yang dirasakan orang lain atas hari besarnya."

"Mengucapkan Selamat Natal atau Selamat Galungan atau Kuningan adalah ungkapan kasih sayang kita kepada sesama umat manusia, Ungkapan kasih sayang itu sebagai tanda bahwa kita respek terhadap orang lain, kita menghargai kepercayaan orang lain."

Sebagaimana Islam juga mengajarkan nilai toleransi agar terbangun persaudaraan kemanusiaan (ukhuwah basyariyah) yang melahirkan sebuah harmoni kehidupan. Sikap saling berbuat kebaikan dalam pergaulan hidup bersama secara damai, karena seorang muslim mempunyai kewajiban untuk bersikap santun terhadap siapa pun, baik dengan sesama muslim maupun dengan non-muslim. Hal tersebut dijelaskan dalam Al-Qur'an QS alMumtahanah ayat 8:

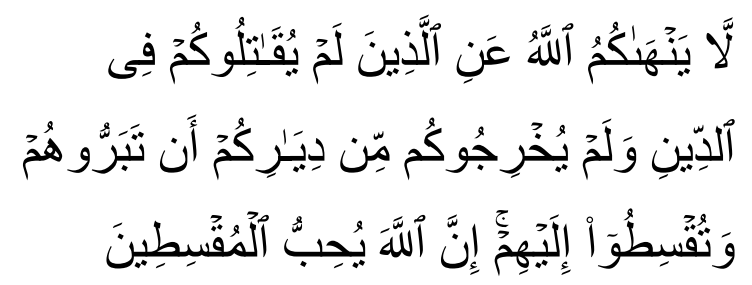

Artinya: "Allah tidak melarang kamu untuk berbuat baik dan berlaku adil terhadap orang-orang yang tiada memerangimu karena agama dan tidak (pula) mengusir kamu dari negerimu. Sesungguhnya Allah menyukai orang-orang yang berlaku adil (QS al-Mumtahanah: 8)"

Dengan demikian, ucapan selamat Natal dalam konteks ini tidak lagi mengarah pada persoalan teologi, tetapi lebih pada hubungan sosial, bahwa di dalam kehidupan sosial ada umat agama lain yang merayakan hari raya mereka, karena itu wajar jika mengucapkan selamat atas hari raya antar pemeluk agama tanpa melibatkan persoalan akidah dan keyakinan.

Dengan mendefinisikan persoalan ucapan selamat Natal sebagai bagaian dari Tolerensi, secara otomatis media NU Online menolak pendapat yang mengharamkan ucapan selamat Natal. Ucapan selamat Natal diframe sebagai sebuah persoalan ijtihadiyyah. Artinya persoalan tersebut tidak terdapat teks Al-Qur'an maupun hadits yang secara tegas melarang atau mengharamkannya. Perbedaan pendapat masing-masing ulama tersebut tentu memiliki argumen tersendiri. Pertama, baik yang mengharamkan, ataupun yang membolehkan. Jadi, sangat wajar apabila persoalan tersebut menjadi objek perbedaan pendapat.

“...karena tidak ada ayat Al-Qur'an dan hadits Nabi yang secara jelas dan tegas menerangkan hukumnya, maka masalah ini masuk dalam kategori permasalahan ijtihadi."

"...baik ulama yang mengharamkannya maupun membolehkannya, sama-sama hanya berpegangan pada generalitas (keumuman) ayat atau hadits yang mereka sinyalir terkait dengan hukum permasalahan ini. Karenanya, mereka berbeda pendapat."

Selanjutnya, dengan melihat persoalan ucapan selamat Natal sebagai persoalan toleransi, sebagai konsekuensi sumber berita dan tokoh yang diwawancarai pun adalah narasumber yang berlatar belakang pro (tidak mengharamkan) terhadap fenomena ucapan selamat Natal, atau minimal orang yang netral dalam memandang ucapan selamat Natal. 
Tabel 2.

Daftar Berita Ucapan Natal di NU Online

\begin{tabular}{ll}
\hline Edisi & \multicolumn{2}{c}{ Berita } \\
\hline Sabtu, & Judul: "Ragam Pendapat Ulama soal \\
22-2- & Mengucapkan Selamat Natal \\
\cline { 2 - 3 } 2018 & Sumber: Ustadz Husnul Haq \\
\cline { 2 - 3 } & $\begin{array}{l}\text { Artikel yang menyajikan perbandingan } \\
\text { pendapat ulama yang mengharamkan } \\
\text { dan membolehkan mengucapkan }\end{array}$ \\
& selamat Natal, serta dasar hukum yang \\
dijadikan landasan
\end{tabular}

\subsection{Diagnose Causes}

Memperkirakan penyebab masalah, merupakan elemen framing untuk membingkai siapa yang dianggap sebagai aktor dari suatu peristiwa. Bagaimana peristiwa dipahami, menentukan apa dan siapa yang dianggap sebagai sumber masalah. Artinya, persoalan yang dipahami secara berbeda, penyebab dari suatu persoalan secara tidak langsung juga akan dipahami secara berbeda pula (Eriyanto 2011).

Dalam berita yang dikemas oleh media NU Online, aktor penyebab masalah ditekankan pada pihak yang mengharamkan ucapan selamat Natal. Letak permasalahan bukan diletakkan pada pihak yang pro (membolehkan) mengucapkan selamat Natal, misal memberikan persaksian palsu dan turut membenarkan keyakinan umat Kristiani (alFurqan, 72), menyerupai tradisi kaum Kristiani (HR. Abu Daud, nomor 4031). Sebaliknya, media NU Online meletakkan masalah pada pihak yang kontra (mengharamkan) mengucapkan selamat Natal karena dinilai berpotensi memicu perpecahan dan konflik. Hal ini misalnya dapat dilihat dalam teks berita yang mendelegitimasi pihak yang kontra (mengharamkan), dan menempatkan pihak yang pro (membolehkan) sebagai korban.

Pendapat Prof. Siti Musdah Mulia yang meminta agar masyarakat tidak terpancing dengan sekelompok orang yang mengharamkan ucapan selamat Natal, meminta untuk kritis sebelum mengikuti pandangan orang lain tentang haramnya ucapan selamat Natal, dan bahkan meminta peran serta seluruh tokoh atau pemuka agama dan pemerintah, yang dihadirkan dalam teks berita juga bagian dari bukti menempatkan pihak yang mengharamkan ucapan selamat Natal sebagai penyebab masalah. Mereka 
kurang lebih diposisikan sebagai ancaman bagi umat Islam secara umum.

"Ia meminta masyarakat agar tidak terpancing pada sekelompok orang yang mengharamkan pengucapan selamat semacam itu. Sebab menurutnya, larangan tersebut hanya akan berdampak buruk pada persaudaraan sesama anak bangsa."

"Masyarakat jangan mudah terpancing. Kita harus kritis sebelum mengikuti pandangan orang lain tentang hal itu. Akal kritis itu harus dipakai, karena di dalam Al-Qur'an diajarkan dalam ayat pertama untuk membaca Iqro. Artinya sebelum melakukan hal yang lain kita harus mencari pemahaman yang benar supaya kita tidak mudah terprovokasi untuk urusan-urusan yang seperti itu." "Untuk itu dirinya meminta kepada seluruh tokoh atau pemuka agama untuk mengajak umatnya agar dapat menjadikan agama sebagai alat untuk merawat solidaritas kemanusiaan. Karena sebagai tokoh agama harus dapat mendorong upaya-upaya persatuan dan kesatuan di seluruh umatnya. Dengan persatuan dan kesatuan itulah bangsa ini nantinya bisa mencapai kemajuan."

"Karena kalau tidak kita dapat terpecah pecah, berkonflik konflik yang akhirnya yang rugi kita sendiri, kita tidak maju-maju sehingga kita selalu menjadi negara yang terbelakang. Dengan modal persatuan dan kesatuan inilah yang membuat negara ini menjadi damai dan harmoni sehingga bisa membangun menuju cita-cita para pendiri bangsa ini."

"Ia juga meminta Pemerintah untuk bertindak tegas dan bersikap adil terhadap pihak-pihak atau kelompok yang berupaya memecah belah masyarakat dengan mengatasnamakan agama. "Misalnya ada orang yang ceramahnya menjelek-jelekkan agama atau kelompok lain maka harus diberikan sanksi. Tidak boleh karena mayoritas maka harus ditolongin, tidak bisa seperti itu."
Dari berita di atas, berita yang dikembangkan adalah berita mengenai bahaya pihak yang mengharamkan, meskipun di sisi yang lain pihak yang mengharamkan juga memiliki dasar hukum yang dijadikan alasan. Mereka berpedoman pada beberapa dalil, di antaranya, Firman Allah Swt surat Al-Furqan ayat 72 :

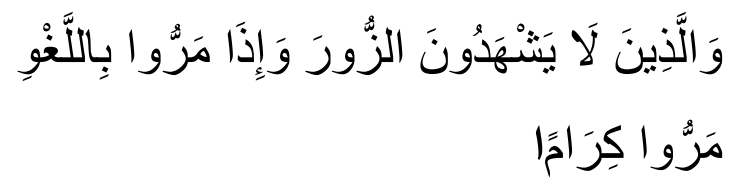

Artinya: "Dan orang-orang yang tidak memberikan persaksian palsu, dan apabila mereka bertemu dengan (orang-orang) yang mengerjakan perbuatan-perbuatan yang tidak berfaedah, mereka lalui (saja) dengan menjaga kehormatan dirinya (AlFurqan: 72)."

Ayat di atas menjelaskan tentang ciriciri orang yang akan mendapatkan martabat tinggi di sisi Allah yaitu orang yang tidak memberikan kesaksian palsu. Sementara seorang muslim yang mengucapkan selamat Natal ditafsirkan telah membenarkan keyakinan Kristiani tentang hari Natal. Oleh sebab itulah mereka dianggap memberi kesaksian palsu. Dengan begitu, mengucapkan selamat Natal dianggap haram pula.

Selain itu, juga berpedoman pada hadits riwayat Ibnu Umar bahwasanya Nabi Saw bersabda:

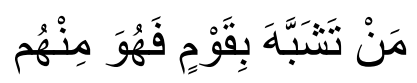

Artinya: "Barangsiapa menyerupai suatu kaum maka dia termasuk bagian kaum tersebut (HR. Abu Daud, nomor 4031).”

Artinya, orang Islam yang

mengucapkan selamat Natal terhadap kaum 
kristiani ditafsirkan telah menyerupai tradisi suatu kaum, sehingga dianggap sebagai bagian dari kaum tersebut. Dengan demikian, haram hukumnya bagi mereka yang mengucapkan selamat Natal.

\subsection{Make Moral Judgement}

Ketika masalah sudah didefinisikan, penyebab masalah sudah ditentukan, dibutuhkan sebuah argumentasi yang kuat untuk mendukung gagasan tersebut. Gagasan yang dikutip berhubungan dengan sesuatu yang familiar dan dikenal oleh khalayak (Eriyanto 2011). Frame media NU Online terhadap ucapan selamat natal sebagai bagian dari Toleransi didukung oleh klaim-klaim moral harmoni hubungan kemanusiaan. Ikut merasakan gembira saat teman gembira, dan sebaliknya ikut merasakan sedih saat teman susah, karena pada prinsipnya ajaran dalam agama Islam, terdapat dua hubungan individu dengan individu yang lainnya: selai hubungan seagama juga terdapat hubungan sekemanusiaan. Berikut beberapa analogi yang dihadirkan dalam teks berita:

“...hal yang bagus manakala
seseorang ikut senang atas
kegembiraan orang lain. Mengapa?
Karena prinsipnya dalam ajaran agama
Islam, hubungan seseorang dengan
orang lainnya ada dua: hubungan
seagama atau hubungan se-
kemanusiaan."
"Ketika bergembira, mari kita ikut
bergembira. Ketika dia bersedih, mari
kita berbelasungkawa."
"Hidup ini baru menjadi indah kalau
kita hidup harmoni. Gembira saat
teman gembira dan sedih saat teman
susah."

Teks berita di atas, secara tegas ingin menegaskan bahwasanya merujuk pada konteks saat ini, di mana umat Islam dan nonmuslim hidup berdampingan saling menghargai dan menghormati, sehingga menjadi wajar jika beberapa ulama sekedar membolehkan ucapan selamat Natal. Artinya, hubungan baik dengan orang lain tidak hanya dibatasi di lingkup sempit sesama agama saja, akan tetapi di luar itu ada ruang lebih luas yang mewadahi keharusan berbuat baik terhadap sesama manusia.

\subsection{Treatment Recommendation}

Treatment Recommendation dipakai untuk menilai apa yang kehendaki media. Jalan apa yang dipilih untuk menyelesaikan masalah, dan hal ini tentu saja sangat bergantung pada bagaimana peristiwa dilihat dan siapa yang dipandang sebagai penyebab masalah dalam sebuah peristiwa (Eriyanto 2011). Media NU Online secara Umum merekomendasikan agar kita menyambut hari Natal dengan mengucapkan selamat hari kelahiran (Selamat Natal). Sebagai penguat media NU Online juga menghadirkan sejarah Nabi Isa dalam Al-Qur'an yang juga melakukan hal serupa dalam teks berita:
"Sehingga kita sambut kehadirannya dengan mengucapkan selamat hari kelahiran dan itu ada di dalam Al- Qur'an. Dalam Al-Qur'an itu, orang pertama yang mengucapkan selamat 'Selamat Natal' adalah Nabi Isa as."
"Wasalamun alayya yauma wulidtu. Salam sejahtera untukku pada hari kelahiranku (Nabi Isa as.), pada hari aku dibangkitkan nanti. Jadi tidak ada masalah sebenarnya."
Namun demikian, media NU Online juga membatasi bahwasanya mereka yang mengucapkan selamat Natal hendaknya hanya 
mereka yang memiliki kepentingan atau memiliki hubungan baik dengan kaum kristiani.

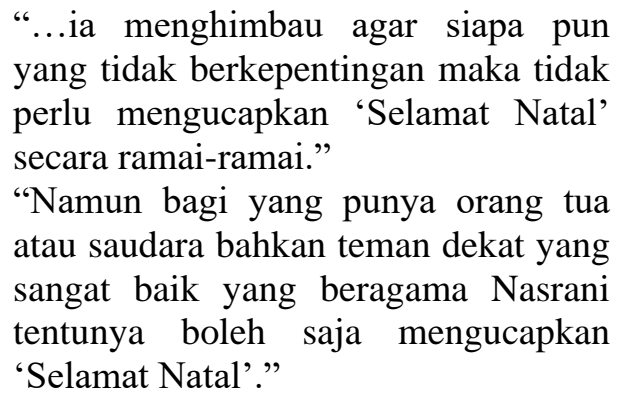

Treatment recommendation ini jelas sebagai konsekuensi logis dari menempatkan persoalan ucapan Natal sebagai bagian dari toleransi (hubungan sosial), bukan sebagai persoalan yang lain seperti teologi ataupun yang lainnya.

Tabel 3.

Konstruksi Berita Ucapan Selamat Natal di Media NU Online: Bagian dari Toleransi

\begin{tabular}{ll}
\hline Elemen Framing & \multicolumn{1}{c}{ Temuan } \\
\hline Define Problems & Mengucapkan selamat \\
& Natal adalah bagian dari \\
& toleransi \\
\hline Diagnoses Causes & Pihak yang mengharamkan \\
& ucapan selamat Natal \\
& sebagai aktor penyebab, \\
& sedangkan pihak yang \\
& terpancing atau \\
& terprovokasi sebagai korban \\
& Harmoni hubungan \\
& kemanusiaan: gembira saat \\
Make Moral & teman gembira, dan sedih \\
Judgement & saat teman susah \\
\hline Treatment & Menyambut kehadirannya \\
Recommendation & dengan mengucapkan \\
& selamat hari kelahiran bagi \\
& yang berkepentingan
\end{tabular}

\section{Simpulan}

Setelah melakukan analisis pada teks berita ucapan selamat Natal di media NU Online edisi Desember 2018 dengan menggunakan analisis framing model Robert Entmant, maka penulis dapat menarik kesimpulan bahwa: NU Online membingkai berita ucapan selamat Natal sebagai bagian dari toleransi, yaitu sebuah tindakan saling menghargai dan menghormati satu sama lain, tanpa harus mengganggu kepercayaan dan keyakinan masing-masing.

Dengan demikian, ucapan selamat Natal dalam frame NU Online tidak lagi mengarah pada persoalan teologi, tetapi lebih pada hubungan sosial, bahwa pada prinsipnya ajaran dalam agama Islam, terdapat dua hubungan individu dengan individu yang lainnya: selain hubungan se-agama juga terdapat hubungan se-kemanusiaan. Ada umat agama lain yang merayakan hari raya mereka, karena itu wajar jika mengucapkan selamat atas hari raya antar pemeluk agama tanpa melibatkan persoalan akidah dan keyakinan. Penelitian ini perlu dilanjutkan pada tahapan yang lebih lanjut (observasi, wawancara dan yang lainnya) mengingat ucapan selamat Natal masih menjadi pro-kontra di masyarakat.

\section{Daftar Pustaka}

Bungin, Burhan. 2008. Konstruksi Sosial Media Massa: Kekuatan Pengaruh Media Massa, Iklan Televisi, dan Keputusan Konsumen serta Kritik terhadap Peter Berger dan Thomas Luckman. Jakarta: Kencana.

Departemen Agama RI. 2002. Al-Qur'an dan Terjemahnya. Jakarta: Bumi Restu. 
Eriyanto. 2011. Analisis Framing: Konstruksi Ideologi dan Politik Media. Yogyakarta: LKiS.

Kovach, Bill, and Tom Rosentiel. 2006. Sembilan Elemen Jurnalisme. Jakarta: Yayasan Pantau.

Liliweri, Alo. 2001. Gatra-Gatra Komunikasi Antar Budaya. Yogyakarta: Pustaka Pelajar.

Maryam, Siti. 2016. "Konstruksi Realitas Dalam Infotainment Silet." Jurnal Aspikom 2 (6).

https://doi.org/http://dx.doi.org/10.24329 /aspikom.v2i6.93.

\section{Sumber Berita:}

Haq, Husnul. "Ragam Pendapat Ulama Soal Mengucapkan Selamat Natal". Diakses dari

http://www.nu.or.id/post/read/100603/rag am-pendapat-ulama-soal-mengucapkanselamat-natal. (23 Agustus 2019).

Muchlishon. "Kata Prof. Quraish Shihab Soal Muslim Ucapkan Selamat Natal". Diakses dari http://www.nu.or.id/post/read/100760/kat a-prof-quraish-shihab-soal-muslimucapkan-selamat-natal (23 Agustus 2019).

Muchlishon. "Imbauan MUI kepada Umat Islam di Hari Natal". Diakses dari http://www.nu.or.id/post/read/100759/im bauan-mui-kepada-umat-Islam-di-harinatal (23 Agustus 2019).

Rozali, Ahmad. "Ucapan Selamat atas Hari Besar Agama Lain adalah Bentuk Penghormatan". Diakses dari http://www.nu.or.id/post/read/100938/uc apan-selamat-atas-hari-besar-agama-lainadalah-bentuk-penghormatan Agustus 2019). 
(Sengaja dikosongkan untuk kebutuhan pengaturan tata letak jurnal)

[Orasi: Jurnal Dakwah dan Komunikasi | Volume 11, No. 1, Juli 2020 